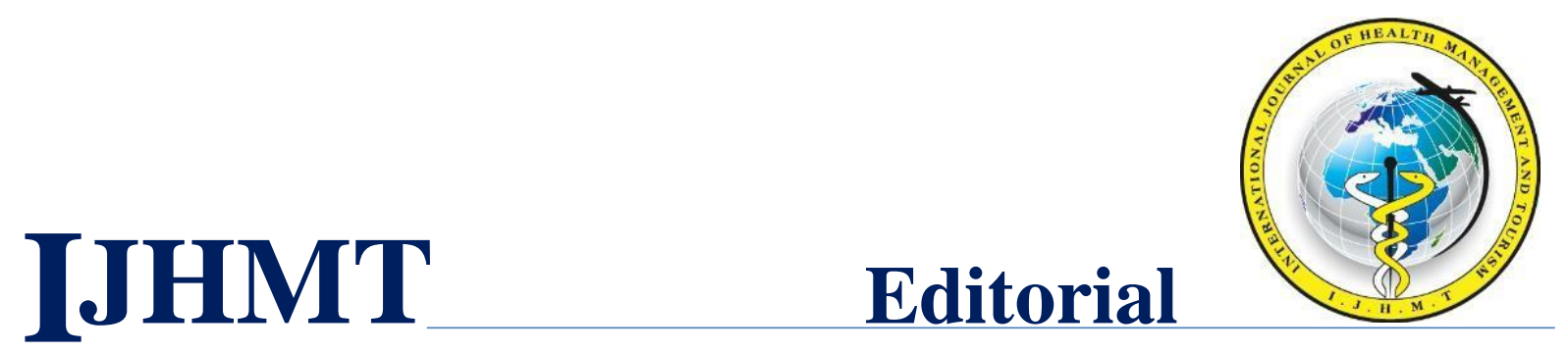

Internatıonal Journal Of Health Management And Tourism

\title{
TRADITIONAL AND COMPLEMENTARY MEDICINE FROM HEALTH TOURISM PERSPECTIVE
}

\footnotetext{
Nurperihan TOSUN ${ }^{1 *}$, Yaşar DEMIR ${ }^{2}$, Erkan SAĞLIK ${ }^{3}$

${ }^{1}$ Assist. Prof., Dep. of Health Management, Sivas Cumhuriyet University, Turkey, nkarabulut@cumhuriyet.edu.tr ORCID Number: 0000-0001-6548-3099

${ }^{2}$ Yaşar DEMİR, Ph.D. Student, Samsun Oral and Dental Health Hospital, ydsimal@ hotmail.com ORCID Number: 0000-0001-9930-8440

${ }^{3}$ Assoc. Prof, Sivas Cumhuriyet University, Department of Tourism Management, esaglik@ cumhuriyet.edu.tr ORCID Number: 0000-0002-2700-658X

Received: 25.02 .2020

Accepted: 01.05.2020

Research Article
}

Abstract: Health tourism, which is defined as travels for treatment, staying fit, protecting and improving health, has become an important source of income for countries in the last 20 years. Depending on globalization and the development of technology, the number of tourists traveling for health purposes is increasing rapidly in the world. In parallel with these increases, the demand for traditional and complementary medicine applications and products in the world is increasing. In Europe, more than 100 million people are traveling to receive these applications, and 25 million people are using traditional and complementary medicine products. These travels and expenditures provide significant income to the national economies. In Turkey, there has been an increase in both investments in health tourism and investments in traditional and complementary medicine applications and products in recent years. Turkey aims to gain more economic gains through its natural beauties, advanced medical infrastructure and recent investments on traditional and complementary medicine. With this conceptual study, it is aimed to address the Concept of traditional and complementary medicine from the perspective of health tourism.

Keywords: Traditional and Complementary Medicine, Medical Tourism, Health Tourism 


\section{Introduction}

Diseases have been constantly changing since the existence of human beings. People have benefited from past experiences and nature to combat diseases from the past to the present, leading to the development of traditional treatment methods (Arslan et al., 2016). The fact that people seek these treatments in a country other than their own country with the globalization process is one of the reasons that promote health tourism ( $\mathrm{Yu}$ and Ko, 2012).

Due to the development of health tourism, it has become an important source of income for the national economies. Many countries have begun to develop new strategies to get a share of this cake and generate more revenue. Especially in Turkey, important studies have been carried out on health tourism in recent years. When the data of the Ministry of Health in 2017 is examined, it is seen that the number of health tourists coming to our country is increasing rapidly and medical tourists spend an average of 9.000 USD for per person in public hospitals and 12.000 USD in private hospitals (Ministry of Health, 2018).

When the recent researches are examined, it has been observed that there are some changes in the treatment tendencies of health tourists. Besides medical treatments, they have begun to demand traditional and alternative treatments that has been revealed by research (Majeed et al., 2017). Visits to traditional and complementary medicine (T\&CM) practitioners and practices increased by more than 30\% between 1995 and 2005 in Australia (WHO, 2013). In another study conducted by Albedah et al. (2013) in Saudi Arabia, it was found that people spend USD 560 per year for T\&CM. In a study conducted by Nahin et al. (2009), it was revealed that US citizens spent a total of USD 14.8 billion on their personal products for natural products in 2008 . In this study, the concept of traditional and complementary medicine will be discussed within the scope of health tourism.

\section{Health Tourism And Types}

Benefiting from health services in another country is not a new phenomenon and should be addressed in a historical context. People have traveled abroad for their own health since ancient times. In the 19th century, for example, there was a tradition in Europe that middle-income people traveled to the cities of Sanus Per Aquam (SPA) in order to drink and get cleansed of the health water which was believed to have health-enhancing qualities. In the 20th century, people began to travel from less developed countries to get a better value for money for the services they seek. However, the ongoing changes in health tourism are distinguished 
quantitatively and qualitatively from the previous types of health-related travel. These fundamental differences have led to visits from developed countries to less developed countries, more regional movements, and the emergence of an international market for people who want to be treated (OECD, 2011).

Health tourism is defined as the type of tourism that enables the growth of health institutions by using the international patient potential in order to improve the physical well-being of the people traveling to therapeutic spas or other health centers or aesthetic surgical operations, organ transplantation, dental treatment, rehabilitation etc. with those in need (Health Tourism Handbook, 2012).

Health tourism is divided into sub-branches as a thermal tourism and spa-wellness, old and disabled tourism and medical tourism. The scope of the services has been provided as preventive, therapeutic and rehabilitative health services. SPA and Wellness tourism within the scope of preventive health services; medical tourism within the scope of medical diagnosis and treatment applications; also elderly and disabled tourism within the scope of rehabilitation services are evaluated. In this context, a parallel was established between the scope of health tourism and general health services (Saturk, 2018; Erdogan, 2018).

\subsection{Thermal Tourism SPA - Wellness}

According to the Ministry of Culture and Tourism, thermal tourism is described that is combined with mineralized thermal waters and sludges with the environmental and climatic factors in the source region and within the scope of expert physician supervision and program in order to make a positive contribution to human health; rehabilitation, physical therapy, psychotherapy etc. support movements such as tourism movements (http://yigm.kulturturizm.gov.tr). Hot water baths, cures, physical therapy and climatotherapy are the most common applications provided within the scope of thermal tourism. Taking advantage of the different features of natural water resources to gain vitality to the body and soul, psychological relaxation is the most important purpose of thermal tourism (Bayer, 1992).

The term wellness refers to fitness in mind and body health. Wellness tourism includes all kinds of massage, skin care, mud bath, algae treatments, thalassotherapy services (Health Tourism Handbook 2012). The term; it consists of the initials of the Latin term us Salus Per Aquam ve and means goodness / health coming by means of water. SPA is a holistic therapy which rests and regenerates people spiritually and physically as well as health from water. Nowadays, SPA 
treatments include besides aesthetics and beauty treatments, massage, phytotherapy, aromatherapy (controlled use of essential oils for physical, mental health and well-being by experts), phangotherapy (mud treatment), snow and ice rooms, salt rooms, sauna, stone therapy and color therapy ect. applications. In addition to this, relaxation is also indicative of a holistic therapy included in SPA treatments with water, hot, cold and different forms of drainage, drip, spray, shower and so on. application (Deger, 2018).

\subsection{Advanced Age and Disability Tourism}

Advanced age tourism has emerged in order to meet the health demands of the increasing elderly population in the world. Organizing excursion tours, organizing occupational therapies and providing rehabilitation services for people of advanced age are evaluated under this classification (Saturk, 2018). Another type of health tourism is disabilty tourism. Disability tourism is the activity of individuals who are able to travel independently or independently. The size of the market in disability tourism wish and needs of people with disabilities should be reevaluated. Barriers in front of transport should be removed for achievement disability tourism international level. It should be organized that access to destination, access to accommodation rooms and tourist areas rooms and living spaces are accessible for disabled people. Facilities should be suitable for disabled people who will carry out health tourism activities themselves by targeting both disabled and aging population and if necessary assistance should be provided. Tourism of elderly and disabled individuals provides a new destination opportunity, especially for countries with young and dynamic populations including in Turkey (Tengilimoglu and Özdemir, 2013).

\subsection{Medical Tourism}

Medical tourism is a type of tourism that comes about in another country which is usually shaped by individuals' desire to have access to high cost, higher quality and technology health services (Yu and Ko, 2012; Özsarı and Karatana, 2013). Medical tourism is a type of health tourism where the physician is at the forefront (Edinsel and Adıgüzel, 2014). They are the travels that are included in the field of classical medicine to receive the treatment services performed by physicians in secondary and tertiary health care institutions (Gürsoy et al., 2017). According to another definition, generally, medical tourism is a tourism activity in order to benefit from the low treatment fees in foreign and other countries due to the expensive treatment costs of patients in their place of residence (Buldukoğlu, 2014). According to Connel (2013), factors 
such as low costs and procedures are mentioned in the definitions. In summary, the travels of an individual to get health services in another country or region are called medical tourism. In addition to the health services provided to medical tourists, resting and leisure time is the touristic dimension of medical tourism and surgical procedures and other medical procedures are considered as medical aspects. In this connection, medical tourism emerges as a result of joint goods and services production of medicine andourismsector(GümüşandBüyük,2008).

\section{Traditional And Complementary Medicine}

The World Health Organization (WHO) defines traditional and complementary medicine (T\&CM) that is a collection of knowledge, skills and practices based on theories, beliefs and experiences specific to different cultures - explicable or inexplicable- that are used in the maintenance of health as well as prevention, diagnosis, improvement or treatment of physical and mental diseases (WHO, 2002).

According to the definition of National Center for Complementary and Alternative Medicine: "Although the concepts of complementary and alternative medicine are used in the same way, these concepts have different meanings. If a drug is used together with traditional medicine, this is complementary medicine, if it is used instead of traditional medicine, this is the concept of alternative medicine', (NIH, 2016).

Traditional medicine, which was used by closed societies before the 1990s, became widespread in developed and developing societies after the 1990s (WHO, 2002). In countries such as China, Korea, Japan, India and Malaysia, T\&CM plays a key role in the treatment of diseases. T\&CM is applied in the world by means of acupuncture, homeopathy, ozone treatment, mesotherapy, massage, ayurveda, aromatherapy, yoga, cryotherapy, thermal treatment, SPA, osteopathy and cup treatment (Biçer and Balçık, 2019).Some of eligible T\&CM applications made in Turkey are listed below (Official Gazette No. 29158 dated 27.10.2014):

- Acupuncture: It is the stimulation of certain points in the body by placing fine needles on the skin.

- Apitherapy: It is the use of bees and bee products as complementary or supportive in certain diseases.

- Phytotherapy: It is a treatment with traditional herbal products and herbal medicines.

- Leech Therapy (Hirudotherapy): It is a treatment with sterile leeches. 
- Homeopathy: It is a treatment method that aims to improve the health of the patient with homeopathic remedies.

- Chiropractic: It is a supportive field of application that deals with the prevention of biomechanical disorders of the muscles, spine and skeletal system and its problems on the nervous system.

- Cup Application (Hacamat): It is a regional dry cup application to increase blood circulation and wet cup application where blood is taken by forming small incision points with vacuum in certain body areas.

Traditional and Complementary Medicine is accepted by WHO as a globally important field that needs to be supported. WHO also expressed an opinion on the policy development of states for the integration of T\&CM practices into health systems (WHO, 2013).

In countries such as the USA, Chile, Cuba, Switzerland and Germany, more than $40 \%$ of the population generally uses traditional and complementary medicine once a year (Park et al., 2016). Traditional Chinese medicine dates back to 2000 years. It is an integral part of Chinese cultural heritage and and it has developed over time and now serves healthcare recipients effectively and productively (Che et al., 2017). In addition, T\&CM usage rate among primary health care services in Africa and South East Asian countries varies between $60 \%$ and $90 \%$ (Ong et al., 2005).

Korean traditional medicine occupies an important place in Korean primary health care. $86 \%$ of the population uses traditional medicine. In the Korean health education system, traditional Korean Medical has a professional status (Han et al., 2016).

In the reports published by WHO; 170 institutions in China, 7 institutes in India, 3 institutes in Japan, 1 institute in Norway, 1 institute in Italy, 1 institute in Canada, 2 associations in Denmark and 35 associations in Belgium have been established until today. The number of public and private hospitals performing T\&CM worldwide; there are 2,500 hospitals in China, 2,860 hospitals in India, 128 hospitals and 206 public health centers in Korea (WHO, 2002; WHO, 2013).

The first regulation in the field of T\&CM in our country was issued in 1991 with the Acupuncture Treatment Regulation (Mollahaliloglu et al., 2015). In 2012, the Department of Traditional and Complementary Medicine Practices was established within the General 
Directorate of Health Services (Official Gazette No. 28103 dated 02.11.2011).In 2014, the regulation on traditional, complementary and alternative medicine practices was issued (Official Gazette No. 29158 dated 27.10.2014). T\&CM Institute was founded in 2014 depending on Turkey Institutes of Health Office. The aim of the T\&CM Institute is to contribute to the protection, improvement, rehabilitation and correction of deterioration of health of individuals by integrating traditional and complementary medicine with modern medicine based on evidence (https://www.tuseb.gov.tr/enstitu/T\&CM/index.php).

According to the Regulation on Traditional and Complementary Medicine Practices issued in 2014; In our country, acupuncture, phytotherapy, apitherapy, leech application, homeopathy, chiropractic, cup application, larval application, mesotherapy, prolotherapy, osteopathy, ozone application, reflexology, musicotherapy applications are performed in certified centers under the supervision of a certified medical Professional (Official Newspaper dated 26.11.2014, numbered 29187).

As of September 2019, the number of T\&CM application centers in Turkey is 64, the number of training centers is 23 and the number of T\&CMunits is 986.41 of the implementation centers are located within the Ministry of Health, 16 of them are State Universities and 7 of them are Foundation Universities. The distribution of training centers is the Ministry of Health 13, State Universities 7 and Foundation Universities 3. 598 of the T\&CM units are doctor's offices, 143 are private hospitals, 122 are medical centers, 79 are public hospitals, 42 are polyclinics, 6 are dental polyclinics, 4 are branch centers and 3 are institutions. The distribution of T\&CM applications and units, which serve only under the Ministry of Health, is seen on the website (https://khgmozellikli.saglik.gov.tr/svg/ozellikli_hizmetler.php?srr=42).

In addition, the website contains summary information about the procedure and the names of the physician or physicians performing the operations in the application center or unit. The total number of health personnel who have T\&CM application certificate is 14.885 . The most common provinces of T\&CM units are Istanbul (289), Ankara (136), Antalya (58), Izmir (54), Bursa (40), Adana (33), Samsun (23), Mugla (21), Denizli (21), Kocaeli (20) and Kayseri (18) (https://T\&CMportal.saglik.gov.tr/).

The payback rates of T\&CM practices are different. T\&CM applications in our country are carried out according to the group that the hospital belongs to through the public sales schedule in public health facilities and fees are paid by health care 
recipients(https://tig.saglik.gov.tr/TR,26173/kamu-saglik-hizmetleri-fiyat-tarifesi-html). In many European countries, the costs of T\&CM applications are partially or not covered by insurance companies. In some of the Far East Asian countries such as China, Japan and North Korea, and in European countries such as Finland and Sweden, T\&CM applications are covered by public health insurance (Biçer and Balçık, 2019).

\subsection{Health Tourism And The Relation Between Traditional And Complementary Medicine}

The increasing demand of health service appears that developments of education and ecenomic global facts. The demographic changes of countries, getting old population and old people's needs for medical service increase the demand of better medical service (Pocock and Phua, 2011). These people wo live in developed countries tend to spend more Money to make beter life quality (Yeung et al., 2013). They tend to receive alternative treatments to be active and alive for a long time, especially when it is observed that the increasing amount of chronic diseases among the old population (Garcia-Altes, 2005). For example obesity is the reason of many chronic diseases. Therefore it is reported that approximately 2,8 million deaths occur every year because of obesity (WHO, 2010). Also it is stated that diabetes has become an epidemic in many countries and the most crowded counties, China and India, take part as the first ones with endocrinologic dieases in the world (Wolfe et al., 2015). The people who don't want to suffer from theese illnesses tend to make changes in their life style. They spend a lot of money for this purpose. Due to that life style problems are seen as the most important reasons of chronic diseases, health tourists prefer total treatments such as pyhsical health, mental health, relaxation, aesthetic surgery, obesity surgery, and losing weight (Chen et al., 2013).

It is seen that approximately $\% 33 \%$ of medical tourists prefer to undergo aesthetic surgeries and have healthy life styles to be active for a long time as a result of the research Majeed et al. (2017). Besides, it is identified that changes of medical tourists' life styles include developing their health and having alternative treatments in this research. This diagram is created by taking experts' opinions about T\&CM that was researched by Firat (2019) 


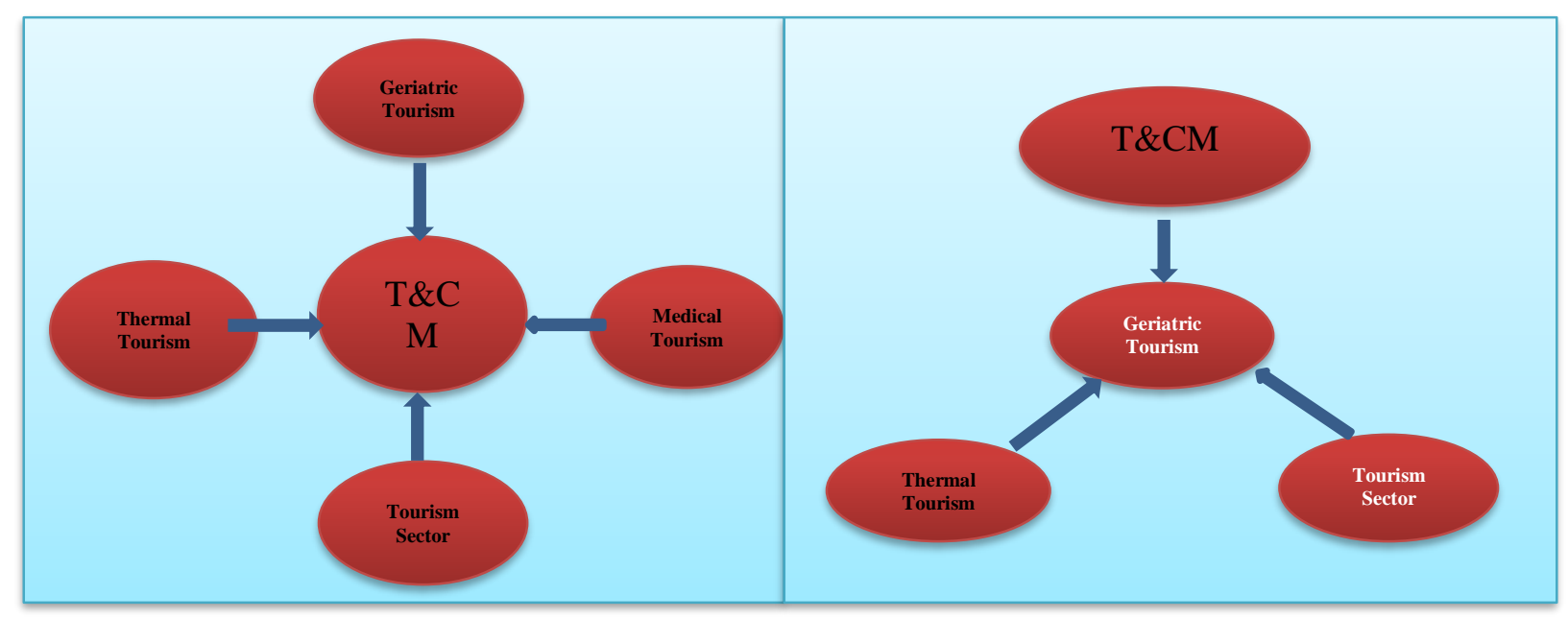

Figure 1. Suggestions of Expert Opinions on T\&CM Positioning

$\mathrm{T} \& \mathrm{CM}$ sector is in the center of other sectors as it is seen in the first diagram. According to the diagram, T\&CM exists with other tourism varieties. The analysis of the second diagram shows that geriatric tourism is in the center instead of T\&CM. Geriatric tourism; that is supported by thermal tourism, medical tourism and traditional and complementary medicine will hopefully provide longer life times for elderly people.

In brief people from all around the world have chronic disease in high level and health costs increase. Both patients and medical service workers are trying to find new solutions by emphasizing to activate the personal care (WHO, 2013).

\section{Conclusions And Suggestions}

Turkey attracts the attention of the citizens of many countries with its geographical structure, climate, natural wealth and relatively high quality and cheap health care. With this abundance, Turkey reveals different products in order to gain more economic benefits from tourism. In this context, T\&CM emerges as a by-product with its supporting feature of health tourism. It is thought that correct implementation of T\&CM services by physicians will contribute to health tourism. When this issue is taken into consideration from Turkey, the fact that it has a rich geography in terms of plants, a large number of physicians are certified for T\&CM applications, has a high potential in terms of thermal tourism and medical tourism, and it is doing it at a more affordable price compared to countries suggestings that T\&CM applications should be positioned in health tourism (Biçer and Balçık, 2019). For this purpose, it is thought that the provision of a T\&CM application in addition to medical treatment by public and private health 
institutions engaged in medical tourism activity will give medical tourists a different experience. Geriatric tourism should be integrated with one or more of the thermal tourism, medical tourism and cittaslow tourism sectors and positioned as a by-product. In slow cities (cittaslow) with high potential for Geriatric tourism, T\&CM products markets should be established and marketed to visitors. In this way, the economic development of these regions will be contributed.

\section{References}

Al-Bedah, AM., Khalil, MK., Elolemy, AT. Al Mudaiheem, AA., Al Eidi, S., Al-Yahia, OA., Al-Gabbany, SA., Henary, BY. (2013). The use of and out-of-pocket spending on and alternative medicine in Qassim province, Saudi Arabia. Ann. $\quad$ Saudi Med., 33(3): 282289.

Arslan M., Sözen Şahne, B. \& Şar S. (2016). Dünya'daki Geleneksel Tedavi Sistemlerinden Örnekler: Genel Bir Bakış. Mersin Üniversitesi Tıp Fakültesi Lokman Hekim Tip Tarihi ve Folklorik Tip Dergisi6(3):100-105.

Bayer, M.Z. ( 1992). Turizme Giriş. İstanbul: İşletme Fakültesi Yayını No:253.

Biçer, İ., Yalçın Balçık P. (2019). Geleneksel Ve Tamamlayıcı Tıp: Türkiye Ve Seçilen Ülkelerin İncelenmesi. Hacettepe Sağllk İdaresi Dergisi, 22(1):245-257.

Buldukoğlu, S. (2014). Sağllk Turizminin Türkiye'deki Yeri ve Önemi, Ufuk Üniversitesi Sosyal Bilimler Enstitüsü, Yüksek Lisans Tezi, Ankara

Che, C. T., George, V., Ijinu, T. P., Pushpangadan P., Andrae-Marobela K. (2017). Traditional Medicine'. In Badal McCreath S., Delgoda R. (ed) Pharmacognosy,Fundamentals, Applications and Strategies, pp 15-30, Academic Press, Boston.

Chen, K.H., Liu, H.H., Chang, H. (2013). Essential customer service factors and the segmentation of older visitors within wellness tourism based on hot springs hotels, Int. J. Hosp. Manag. 35,122-132.

Connell, J. (2013). Contemporary Medical Tourism: Conceptualisation, Culture and Commodification, Elsevier - Tourism Management 34, p. 1-13

Değer, M. (2018). Rekreaktif Etkinlik Açısından Sağlıklı Yaşam Merkezlerindeki (SPA) Hizmet Kalitesinin Belirlenmesi: Ankara'daki Beş Yıldızlı Otellerde Bir Uygulama. Doktora Tezi, Gazi Üniversitesi, Ankara.

Edinsel, S. and Adıgüzel, O. (2014). Türkiye'nin Sağlık Turizmi Açısından Son Beş Yıldaki Dünya Ülkeleri İçindeki Konumu ve Gelişmeleri, Çankırı Karatekin Üniversitesi İ̈BF Dergisi, 4(2), ss. 167-190

Erdoğan, M. (2018). Kamu Sağlık Politikalarında Yeni Bir Açılım Sağlık Turizmi: SDÜ Hastanelerinde Çalışan Hekimlerin Sağlı Turizmi Farkındalığı Üzerine Bir Araştırma, Süleyman Demirel Üniversitesi Sosyal Bilimler Enstitüsü, Yüksek Lisans Tezi, Isparta

Fırat, S.(2019). Düzce İlinin Geleneksel ve Tamamlayıcı Tıp (T\&CM) Sektörünün Uluslarası Rekabetçilik Analizi. Düzce Üniversitesi Sosyal Bilimler Enstitüsü Sağlık Yönetimi Ana Bilim Dalı Yüksek Lisans Tezi: Düzce. 
Garcia-Altes, A. (2005). The development of health tourism services. Annals of Tourism Research, 32, 262-266.

Gümüş, F. and Büyük, Ö. (2008). Sağlık Turizminde Yeni Açılımlar: Tıp Turizmi, III. Balıkesir Ulusal Turizm Kongresi Kongre Bildiri Kitab1: 433-442.

Gürsoy, Y., Akgöz, E., Topuz, Ç. (2017)ç Giresun İli Sağlık Turizmi Potansiyelinin Değerlendirilmesi,Uluslararast Sosyal Araştırmalar Dergisi. 773-785 Wolfe, K., Stephano, R.M., Harkins, J. (2015). Lifestyle Medicine: Opportunities for the Wellness Tourism Industry, Medical Tourism Magazine, 2015, pp. 72-73

Majeed, S., Lu, C., Javed, T. (2017). The Journey From Allopatic To Naturel Treatment Approach: A Scoping Review Of Medical Tourism And Health Systems. European Journal Of Integrative Medicine, 16, 22-32.

Mollahaliloğlu, S., Uğurlu, F. G., Kalayc1, M. Z. and Öztaş, D. (2015). Geleneksel ve Tamamlayıc1 Tip Uygulamalarında Yeni Dönem, Ankara Medical Journal15(2): 102105.

Nahin, R. L., Barnes, P. M., Stussman, B. J., Bloom, B. (2009). Costs of complementary and alternative medicine (CAM) and frequency of visits to CAM practitioners: United States, 2007. Natl Health Stat Report, (18):1-14.

NationalInstitutes of Health (NIH) https://nccih.nih.gov/health/integrativehealth\#cvsa Retrieved 08.03.2018

Yeung, O., Johnston, K., Chan. N. (2013). The Global Wellness Tourism Economy, Global Wellness Institute \& SRI International, New York

OECD.(2011). Medical Tourism: Treatments, Markets and Health System Implications: A scoping review, Paris: OECD, s. (1-55).

Ong, C. K., Bodeker, G., Grundy, C., Burford, G. and Shein, K. (2005).WHO Global Atlas of Traditional, Complementary and Alternative Medicine. World Health Organization Centre for Health Development, Kobe, Japan.

Özsarı, S.H. and Karatana, Ö. (2013). Sağlık Turizmi Açısından Türkiye'nin Durumu, Kartal TR 24(2), 136-144.

Park, Y. L., Huang, C. W., Sasaki, Y., Ko, Y., Park, S. and Ko, S.G. (2016). Comparative Study on The Education System of Traditional Medicine in China, Japan, Korea, and Taiwan. Explore 12(5):375-383

Pocock, N. S., Phua, K. H. (2011). Medical tourism and policy implications for health systems: a conceptual framework from a comparative study of Thailand, Singapore and Malaysia. Global Health. 7:12.

Official Newspaper. (2011).Sağlık Bakanlığı Ve Bağlı Kuruluşlarının Teşkilat Ve Görevleri Hakkında Kanun Hükmünde Kararname. Date: 02.11.2011;numbered: 28103.

Official Newspaper.(2014).Geleneksel ve Tamamlayıcı Tıp Uygulamaları Yönetmeliği. Date:27.10.2014; numbered:29158.

Official Newspaper. (2014). Türkiye Sağlık Enstitüleri Başkanlığı Kurulması ile Bazı Kanun ve Kanun Hükmünde Kararnamelerde Değişiklik Yapılmasına DairKanun. Date:26.11.2014;numbered:29187. 
Tengilimoğlu, D. and Özdemir, D. (2013). İleri Yaş Ve Engelli Turizmi. In:Tengilimoğlu, D. (ed.) Sağlık Turizmi. Siyasal Kitabevi, Ankara, pp.123-141.

WHO. (2013).WHOTraditionalMedicineStrategy:2014-2023

https://apps.who.int/iris/bitstream/handle/10665/92455/9789241506090_eng.pdf;jsessionid=3 F43106AFE135F5C98C4A81CB2600B7D?sequence=1Retrieved 15.11.2019

WHO.(2002).WHOtraditionalmedicinestrategy:2002-2005.

https://apps.who.int/iris/bitstream/handle/10665/67163/WHO_EDM_TRM_2002.1.pdf?seque $\underline{\text { nce }=1 \text { Retrieved15.11.2019 }}$

WHO. (2010). Global status report on noncommunicable diseases. https://www.who.int/nmh/publications/ncd_report_summary_en.pdf?ua=1Retrieved 15.11.2019

Yu, J. \& Ko, T. (2012). A cross-cultural study of the perceptions of medical tourism among Chinese, Japanese and Korean tourists in Korea.Tourism Management, 33, pp. 80-88

T.C. Sağlık Bakanlığı. (2018). Faaliyet Raporu 2017, Ankara, Yayın no:1092,Vega Basım Hizmetler.

T.C. Sağlık Bakanlı̆̆ı. (2012).Să̆llk Turizmi El Kitabı, T.C. Sağlık Bakanlı̆̆ı Sağlık Hizmetleri Genel Müdürlüğü,Ankara

https://dosyasb.saglik.gov.tr/Eklenti/493,saglik-turizmi-el-kitabi-08052012pdf.pdf?0Retrieved 13.11.2019

https://www.tuseb.gov.tr/enstitu/T\&CM/index.phpRetrieved 13.11.2019

https://T\&CMportal.saglik.gov.tr/Retrieved 13.11.2019

https://tig.saglik.gov.tr/TR,26173/kamu-saglik-hizmetleri-fiyat-tarifesi-html

Retrieved 13.11.2019

https://khgmozellikli.saglik.gov.tr/svg/ozellikli_hizmetler.php?srr=42Retrieved 13.11.2019

http://yigm.kulturturizm.gov.trRetrieved 13.11.2019

http://saturk.gov.tr/images/pdf/tyst/07.pdfRetrieved 13.11.2019 